А.В. Лисиця, С.В. Гузченко, С.М. Телюков, Д.М. Козлов

Харківський наиіональний університет Повітряних Сил ім. І. Кожедуба, Харків

\title{
АНАЛІЗ ВПЛИВУ ЗАХИСНИХ ВЛАСТИВОСТЕЙ ЗАСОБІВ ІНДИВІДУАЛЬНОГО БРОНЬОВАНОГО ЗАХИСТУ НА НЕОБХІДНУ КІЛЬКІСТЬ БОЄПРИПАСІВ ДЛЯ ПОРАЖЕННЯ ЖИВОЇ СИЛИ ПРОТИВНИКА ЗІ СТРІЛЕЦЬКОЇ ЗБРОЇ
}

У статті проведено аналіз впливу захисних властивостей засобів індивідуального броньованого захисту на витрату боєприпасів для пораження захищеної иілі. Досліджується зміна очікуваної кількості патронів, необхідної для ураження захищеної иілі в залежності від виду зброї, типу патрону на відстані ефективної стрільби зі стрілецької зброї. Дано огляд залежності імовірності пораження захищеної цілі та очікуваної кількості патронів, зроблено висновок, щзодо впливу класу захисної структури бронежслета на витрату патронів різних калібрів. Розглянуто актуальність пораження захищених иілей противника засобами індивідуально броньованого захисту виготовлених з високоякісних полімерних матеріалів: “Арус” $i$ “Русар”. Результати роботи можуть бути використані для обтрунтування правил стрільби по захищених ичілях, а також при уточненні таблиць стрільби зі стрілецької зброї: розрахунків кількості патронів, необхідних для пораження одиночної захищеної ичілі.

Ключові слова: засіб індивідуального броньованого захисту, ефективна дальність стрільби, імовірність пораження цүілі, очікувана кількість патронів, захисний коефіцієнт цүілі.

\section{Вступ}

Постановка проблеми. Сучасний досвід військових конфліктів свідчить, що в бойових умовах військами систематично використовуються засоби індивідуального броньованого захисту (ЗІБЗ).

Наприкінці XX ст. - на початку XXI ст. військово-технічні досягнення, щодо створення сучасних ЗІБ3, вирішують завдання розробки універсального бронежилета, зручного в експлуатації і такого, що забезпечував би захист одночасно від комплексу засобів пораження: осколків, куль малого та великого калібрів, інших факторів [1]. В умовах ведення бойових дій на Сході України, на командирів усіх рівнів покладено функції щодо контролю застосування 3ІБ3, та вжиття вичерпних заходів для захисту здоров'я і життя особового складу [2].

На сьогодні, найкращими полімерними матеріалами для виготовлення ЗІБЗ з високими захисними якостями є: російські “Арус" і "Русар”; американські "Kevlar" i "Spectra". Зазначені матеріали надто міцні, здатні зупинити кулю, зруйнувати іiі сталеву оболонку і одночасно легші за високоміцну сталь [1].

У зв'язку з цим можна визначити два шляхи підвищення ефективності пораження захищеної одиночної цілі зі стрілецької зброї:

- виготовлення патронів 3 кулями підвищеної пробивної здатності;

- збільшення кількості патронів, необхідної для гарантованого пораження цілі, яка має ЗІБЗ.

Норми бойового забезпечення, які грунтуються на дослідженнях закономірностей процесів виконан- ня стрільб, не враховують наявність захисних засобів на об'єктах пораження [3].

Таким чином, необхідно провести аналіз впливу захисних властивостей ЗІБЗ на кількість патронів, необхідних для гарантованого пораження одиночної цілі зі стрілецької зброї (наприклад, для автомата АК-74). Але, взагалі аналіз та супутні розрахунки повинні забезпечити отримання результатів і для інших видів зброї, тобто мати універсальний характер.

Аналіз останніх досліджень і публікацій. В проаналізованій літературі [3-5] розглядаються питання щодо визначення необхідної кількості патронів для пораження поодинокої цілі, визначення запасу і витрати боєприпасів в бою. Разом з тим, в цих питаннях не враховується наявність у цілі ЗІБЗ певного класу, що може значно впливати на розрахунок запасів і витрати патронів для визначення гарантованого способу пораження захищеної цілі.

У роботі [6] запропонована методика визначення узагальненого показника ефективності стрілецької зброї, яка дозволяє проводити всебічне порівняння існуючих зразків стрілецької зброї з використанням як їх тактико-технічних характеристик, характеристик боєприпасів, так і показників ефективності стрільби та надійності зброї в процесі застосування. Але в даній методиці не визначено, як обчислюється важливий критерій ефективності стрільби: імовірність пораження одиночної цілі, яка має ЗІБЗ. Не враховуються енергетичний потенціал куль, захисна площа ЗІБЗ, площі захищених і незахищених ділянок цілі. 
Мета статті - аналіз впливу захисних властивостей ЗІБЗ на величину витрати патронів стрілецької зброї, що грунтується на процесі оцінювання ефективності стрільби по захищених цілях.

\section{Виклад основного матеріалу}

Оцінювання ефективності стрільби зі стрілецької зброї по захищених цілях здійснюється у наступній послідовності:

- визначається вогнева задача стрільби, вид зброї, положення для стрільби, умови ведення вогню, тип патрона, калібр кулі, вага кулі, початкова швидкість кулі, кінетична енергія кулі у момент зустрічі з ціллю, клас захисту ЗІБЗ, енергетичний потенціал ЗІБ3, загальна площа цілі, площа не захищеної ділянки цілі, площа захищеної ділянки цілі, критерії ефективності: імовірність пораження цілі, яка має ЗІБЗ, середньоочікувана витрата патронів;

- виконується оцінювання імовірності пораження та очікуваної витрати патронів на ефективній дальності стрільби зі стрілецької зброї;

- проводиться аналіз впливу на імовірність пораження та середньоочікувану витрату патронів різних конструктивних параметрів засобу ІБЗ на ефективній відстані стрільби 3 метою уточнення розрахунків [3];

- розробляються рекомендації, щодо порядку визначення середньоочікуваної витрати патронів необхідних для знищенні цілей противника, які мають ЗІБЗ.

Під вогневою задачею стрільби, розуміється пораження (виведення з ладу) живої сили противника, що має ЗІБЗ, тобто завдання шкоди, яка перешкоджає виконувати свої бойові завдання протягом тривалого часу.

В якості показника заподіяної шкоди може бути використана імовірність пораження цілі - імовірність того, що живій силі противника будуть нанесені такі фізичні пошкодження, які не дозволять їй продовжувати виконання своїх обов'язків в бою [13]. Найбільш розповсюдженими видами цілей, що можуть бути знищені вогнем з автоматичної зброї є особовий склад противника. За умови обов'язкової наявності ЗІБЗ у живої сили противника, як ціль для стрілецької зброї, будемо розглядати ії у якості технічної системи, що має незахищені і захищені ділянки. При влученні кулі в першу (незахищену) ділянку вона виводить ціль з ладу, і для пораження (знищення) цілі достатньо хоча б одного влучення.

При влученні кулі в іншу (захищену) ділянку, вона завдає шкоду, величина якої залежить від: кінетичної енергії кулі, конструктивних особливостей ЗІБЗ, фізичних особливостей тіла людини. Тобто, одне влучення кулі в технічну ціль, не завжди гарантує, що ӥй буде завдана критична поразка. В такому випадку хоча б одне влучення не може бути використано в якості випадкової величини імовірності по- раження цілі [7]. Для розуміння природи захисту живої сили, розглянемо основні ЗІБЗ, що захищають від стрілецької зброї - це бронежилети та бронешолом. В якості типових ЗІБЗ розглянемо бронежилети 6Б-23 та 6Б43, бронешолом 6Б7-1М, оскільки у 70\% бойових підрозділів вони складають штатне озброєння, виготовляються із застосуванням полімерних матеріалів “Арус" i “Русар" [8].

За рівнем захисту конструкція вказаних бронежилетів має як протиосколкові, так і протикульові захисні композиції з різним ступенем захищеності грудної та спинної секції. На (рис. 1-3) наведено: бронежилет 6Б23, який відноситься до класу захисту Бр. 4, бронежилет 6Б43 до класу захисту Бр. 5, бронешолом 6Б7-1М відноситься до класу захисту Бр. 1. Порогове значення кінетичної енергії кулі, яку здатний витримати ЗІБЗ, $E_{б ж}$ (Дж) було визначено у роботі [9]. Класи захисних структур з тактикотехнічними характеристиками ЗІБЗ наведено в (табл. 1).

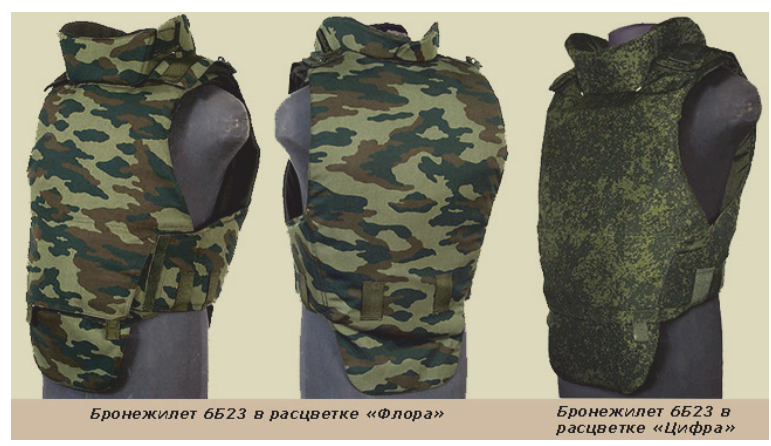

Рис. 1. Бронежилет 6Б23

Джерело: розроблено авторами за даними [8].

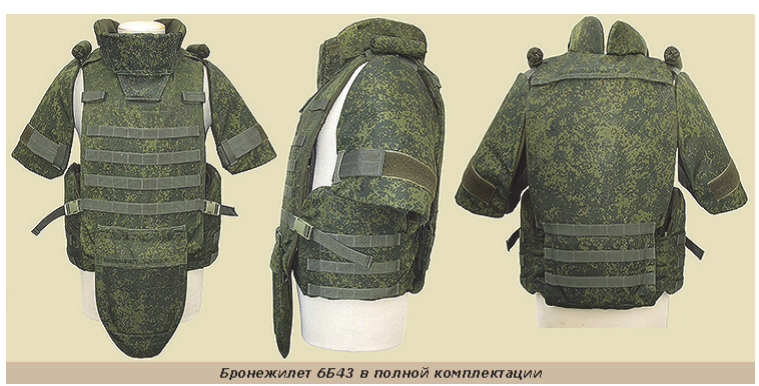

Рис. 2. Бронежилет 6Б43

Джерело: розроблено авторами за даними [8].

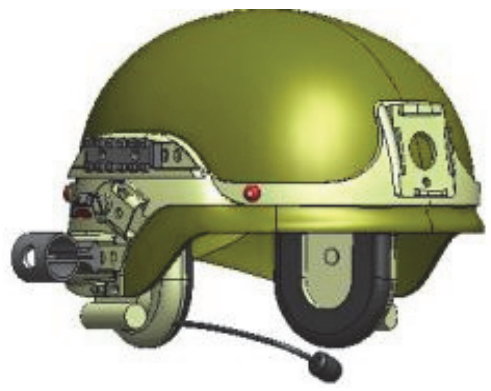

Рис. 3 Бронешолом 6Б7-1М

Джерело: розроблено авторами за даними [8]. 
Таблиця 1

Класи захисних структур з тактико-технічними характеристиками ЗІБЗ

\begin{tabular}{|c|c|c|}
\hline $\begin{array}{c}\text { Клас захисної } \\
\text { структури } \\
\text { (тип ЗІБ3), } \\
\text { матеріал }\end{array}$ & $\begin{array}{c}\text { Порогове } \\
\text { значення кінетичної } \\
\text { енергї̈ кулі, яку } \\
\text { здатний } \\
\text { витримати ЗІБ3 } \\
E_{\text {бж }} \text { (Дж) }\end{array}$ & $\begin{array}{c}\text { Площа } \\
\text { захисту } \\
\text { ЗІБ3 } \\
S_{\text {заx }}\left(\mathrm{m}^{2}\right)\end{array}$ \\
\hline $\begin{array}{c}\text { Бр1(6Б7-1М), } \\
\text { "Русар" }\end{array}$ & 331,064 & $\begin{array}{l}S^{\sigma u}= \\
0,127\end{array}$ \\
\hline $\begin{array}{c}\text { Бр4 (6Б23) } \\
\text { "Pусар" }\end{array}$ & 1724.737 & $\begin{array}{c}S^{\sigma ж}= \\
0,48\end{array}$ \\
\hline $\begin{array}{c}\text { Бр5(6Б43) } \\
\text { "Арус" }\end{array}$ & 3324.775 & $S^{\sigma \varkappa}=0,5$ \\
\hline
\end{tabular}

Джерело: розроблено авторами за даними [8-9].

На рис. 4 наведено найбільш розповсюджені патрони для стрілецької зброї , що перебувають на озброєнні Збройних Сил України, тому подальший розгляд матеріалу проведемо на прикладі цих боєприпасів.

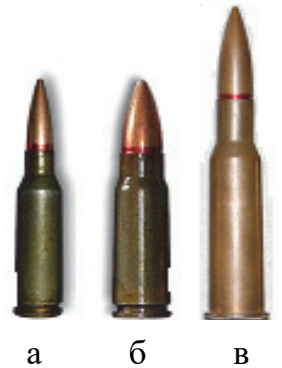

Рис. 4. Патрони за видом зброї:

a - 5,45-мм патрон 3 кулею зі сталевим осердям

(ПС) для (АК74, РПК74); б - 7,62-мм патрон зразка

1943 р. $з$ кулею зі сталевим осердям (ПС) для

(Вулкан-М, АКМ, АК-ТК); в - 7,62-мм гвинтівочний патрон з кулею зі сталевим осердям (ЛПС) для (СВД, ПК)
Для гарантованого пробиття захищеної ділянки цілі, куля повинна мати кінетичну енергію у точці зустрічі з захисним елементом засобу індивідуального броньованого захисту значно більшу або однакову 3 пороговим значенням кінетичної енергії, що може витримати захисний елемент засобу індивідуального броньованого захисту [9].

Тобто, повинна виконуватись умова:

$$
E_{\kappa} \geq E_{\text {бж }},
$$

де $E_{\kappa}$-кінетична енергія кулі у точці зустрічі 3 ціллю (Дж);

$E_{б ж}-$ порогове значення величини кінетичної енергії, яке спроможний витримати захисний елемент бронежилета (Дж).

При визначенні очікуваної витрати кількості патронів $N$ для знищення захищеної одиночної цілі на ефективній дальності стрільби зі стрілецької зброї, можна стверджувати, що при виконанні зазначеної умови (1) забезпечується гарантоване пробиття засобу індивідуального броньованого захисту та пораження цілі однією кулею.

Кінетична енергія кулі у момент зустрічі з ціллю, може бути розрахована за формулою [10]:

$$
E_{\kappa}=\frac{m_{\kappa} \cdot V_{\kappa}^{2}}{2},
$$

де $E_{\kappa}$ - кінетична енергія кулі у точці зустрічі 3 ціллю (Дж);

$$
\begin{aligned}
& m_{\kappa}-\text { маса кулі (кг); } \\
& V_{\kappa} \text { - швидкість кулі у цілі (м/с). }
\end{aligned}
$$

Кінетична енергія кулі у точці зустрічі з ціллю для визначених боєприпасів на дальності ефективної стрільби була визначена за формулою (2) у роботі [9].

Значення кінетичної енергії кулі у точці зустрі-

\begin{tabular}{|c|c|c|c|c|c|c|c|c|c|c|c|c|c|c|c|}
\hline \multirow{2}{*}{$\begin{array}{l}\text { № } \\
\text { 3/п }\end{array}$} & \multirow{2}{*}{$\begin{array}{c}\text { Вид } \\
\text { зброї }\end{array}$} & \multirow{2}{*}{$\begin{array}{c}\text { Тип } \\
\text { патрону }\end{array}$} & \multirow{2}{*}{$\begin{array}{c}\text { Маса } \\
\text { кулі } \\
m_{\kappa} \\
(г)\end{array}$} & \multirow{2}{*}{$\begin{array}{c}\text { Початкова } \\
\text { швидкість } \\
\text { кулі } \\
V_{\kappa}(\text { м/с) }\end{array}$} & \multirow{2}{*}{$\begin{array}{c}\text { Дульна } \\
\text { енергія } \\
\text { кулі } \\
E_{\kappa} \\
\text { (Дж) } \\
\end{array}$} & \multicolumn{10}{|c|}{$\begin{array}{c}\text { Кінетична енергія кулі } E_{\kappa} \text { (Дж) у точці зустрічі з ціллю } \\
\text { на дальності стрільби } D \text { (м) }\end{array}$} \\
\hline & & & & & & 50 & 100 & 150 & 200 & 250 & 300 & 350 & 400 & 450 & 500 \\
\hline 1 & 2 & 3 & 4 & 5 & 6 & 7 & 8 & 9 & 10 & 11 & 12 & 13 & 14 & 15 & 16 \\
\hline 1. & АК-74 & $\begin{array}{c}5,45 \times 39 \mathrm{MM} \\
\text { ПС }\end{array}$ & 3,4 & 900 & 1377 & $\stackrel{0}{\stackrel{\Xi}{I}}$ & $\stackrel{+}{\stackrel{t}{0}}$ & $\frac{d}{d a}$ & $\underset{\substack{f \\
\infty}}{\infty}$ & 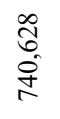 & $\begin{array}{l}\hat{\tilde{z}} \\
\hat{\forall} \\
\hat{b}\end{array}$ & 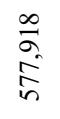 & 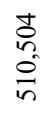 & 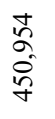 & $\begin{array}{l}n \\
m \\
\infty \\
\infty \\
\hat{m}\end{array}$ \\
\hline 2. & РПК-74 & $\begin{array}{c}5,45 \times 39 \mathrm{MM} \\
\text { ПС }\end{array}$ & 3,4 & 960 & 1567 & 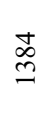 & $\stackrel{\widetilde{\Xi}}{\Xi}$ & $\stackrel{8}{\stackrel{\infty}{0}}$ & 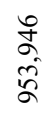 & 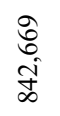 & 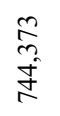 & $\begin{array}{l}y^{2} \\
\tilde{n} \\
\tilde{n}\end{array}$ & $\begin{array}{l}+ \\
\infty \\
\infty \\
\infty \\
\infty\end{array}$ & $\begin{array}{l}\infty \\
\stackrel{\infty}{\infty} \\
\stackrel{\infty}{n}\end{array}$ & 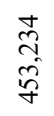 \\
\hline 3. & $\begin{array}{l}\text { Вулкан- } \\
\text { М } \\
\text { АК-ТК } \\
\text { АКМ }\end{array}$ & $\begin{array}{c}7,62 \times 39 \mathrm{MM} \\
\Pi \mathrm{C}\end{array}$ & 7,9 & 715 & 2019 & $\stackrel{\text { : }}{\Xi}$ & 考 & 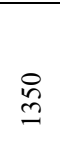 & $\stackrel{\infty}{=}$ & ఠิ & 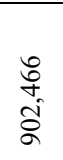 & $\stackrel{\infty}{\stackrel{\infty}{\infty}} \underset{\infty}{\infty}$ & $\begin{array}{l}2 \\
\stackrel{\infty}{\infty} \\
\infty \\
\infty\end{array}$ & $\frac{n}{m}$ & $\begin{array}{l}\infty \\
\tilde{N} \\
\stackrel{\sim}{n} \\
\sim\end{array}$ \\
\hline
\end{tabular}
чі $з$ ціллю наведено в (табл. 2).

Таблиця 2

Кінетична енергія кулі у точці зустрічі з ціллю 
Закінчення табл. 2

\begin{tabular}{|c|c|c|c|c|c|c|c|c|c|c|c|c|c|c|c|}
\hline 1 & 2 & 3 & 4 & 5 & 6 & 7 & 8 & 9 & 10 & 11 & 12 & 13 & 14 & 15 & 16 \\
\hline 4. & ПК & \multirow{2}{*}{$\begin{array}{c}7,62 \times 54 \mathrm{MM} \\
\text { ЛПС }\end{array}$} & \multirow{2}{*}{9,6} & 825 & 3267 & $\begin{array}{l}\text { ते } \\
\text { ते }\end{array}$ & ্ָতু & กี & $\stackrel{\infty}{\stackrel{\infty}{\sim}}$ & $\begin{array}{l}\stackrel{\infty}{\infty} \\
\stackrel{\infty}{a}\end{array}$ & $\hat{\underline{b}}$ & $\frac{n}{n}$ & $\begin{array}{l}8 \\
\stackrel{0}{n}\end{array}$ & $\stackrel{\vec{\beth}}{\underline{\beth}}$ & $\tilde{\delta}$ \\
\hline 5. & СВД & & & 830 & 3307 & $\begin{array}{l}\text { đे } \\
\text { ¿े }\end{array}$ & 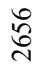 & $\begin{array}{l}\infty \\
\underset{\sim}{\sim}\end{array}$ & $\stackrel{m}{\vec{v}}$ & $\approx$ & $\underset{\Xi}{ \pm}$ & $\begin{array}{l}\infty \\
\end{array}$ & 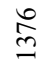 & $\stackrel{\Xi}{\Xi}$ & $\stackrel{\bullet}{\varrho}$ \\
\hline
\end{tabular}

Джерело: розроблено авторами за даними [9].

Використовуючи визначені значення у (табл. 2), пропонується дослідити залежність імові-

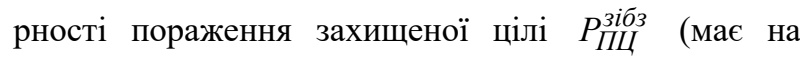
оснащенні ЗІБЗ класу захисту Бр. 4, Бр. 5) на ефективній дальності стрільби $D$ зі стрілецької зброї для заданих видів та типів патронів до неї.

У роботі [11] пропонується визначення $P_{П Ц}^{3 і б з}$ за формулою:

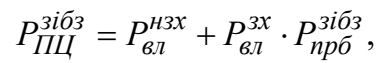

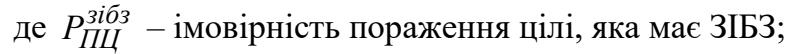

$P_{8 л}^{H з x}$ - імовірність влучення кулі у незахищену ділянку цілі, яка має ЗІБЗ;

$P_{8 л}^{3 x}$ - імовірність влучення кулі у захищену ділянку цілі, яка має ЗІБЗ;

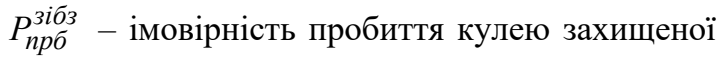
ділянки цілі, яка має ЗІБЗ.

У роботі [3] за знайденими значеннями $P_{П Ц}^{3 і б з ~}$ визначається очікувана кількість патронів $N_{O Д}^{3 і б з ~ д л я ~}$ пораження одиночної захищеної цілі формулою:

$$
N_{O Д}^{\text {зібз }}=\frac{S}{P_{П Ц}^{\text {зібз }},}
$$

де $N_{O Д}^{\text {зібз }}$-кількість патронів;

$S$ - число пострілів ( $S=1$ для одиночного вогню);

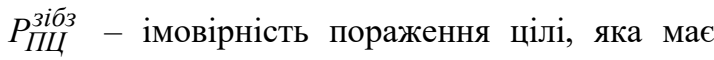
ЗІБЗ.

Для проведення розрахунків досліджуваних показників необхідно визначити умови стрільби:

1. Ціль - стрілець, що атакує (мішень № 8), спостерігається стрільцем на усій дальності стрільби: від 0 до 500 м. Загальна площа цілі $S_{u}=0,64 \mu^{2}$ [3]. Площі захищених ділянок цілі змінюються у відповідності до класу захисної структури ЗІБЗ, визначені у (табл. 1).

2. Спосіб стрільби - одиночним пострілом для зазначених видів стрілецької зброї, в (табл. 2).

Під стрільбою одиночним пострілом будемо розуміти таку стрільбу, при якій наведення зброї в ціль проводиться кожен раз наново перед кожним пострілом. За способом ведення вогню, ціль обстрілюють узгоджено у середину цілі, кожна куля на- правляється в одну й ту саму точку прицілювання на цілі, а розкидування точок влучення на цілі пояснюється розсіюванням боєприпасів. Для зазначених умов ведення вогню та обраних зразків стрілецької зброї, на дальності стрільби в 500 м., площа еліпсу розсіювання куль, не виходить за межі розмірів цілі, що забезпечує гарантовану імовірність влучення у ціль. Отже, вказана дальність є ефективною для обраних зразків стрілецької зброї.

3. Стрілець - навчений прийомам та правилам стрільби із зазначених зразків стрілецької зброї військовослужбовець. Положення для стрільби: стоячи iз окопу з упору (стоячи із окопу 3 сошок). Зброя технічно справна та приведена до нормального бою. Погодні умови не впливають на підготовку вихідних даних та результати стрільби.

Групи похибок при стрільбі у розрахунках не враховуються.

Для обчислення імовірностей влучення кулі у незахищену або захищену ділянки цілі, що входять у формулу (2), пропонуємо застосувати спосіб співвідношення між площами незахищених або захищених ділянок до загальної площі самої цілі [10; 12].

Таким чином, вираз для імовірності влучення кулею у незахищену ділянку цілі можна записати у вигляді:

$$
P_{\text {вл }}^{H 3 x}=\frac{S^{H 3 x}}{S_{u}},
$$

де $P_{8 л}^{\mu 3 x}$-імовірність влучення кулі у незахищену ділянку цілі, яка має ЗІБЗ;

$S^{\text {нзx }}$ - площа незахищеної ділянки цілі $\left(S^{H 3 x}=S_{u}-S^{3 x}\right)\left(\mathrm{M}^{2}\right) ;$

$S_{u}$ - загальна площа цілі $\left(\mathrm{M}^{2}\right)$.

Вираз для імовірності влучення кулею у захищену ділянку цілі, тобто яка має ЗІБЗ, можна записати у наступному вигляді:

$$
P_{8 \pi}^{3 x}=\frac{S^{3 x}}{S^{u}},
$$

де $P_{\text {вл }}^{3 x}$-імовірність влучення кулі у захищену ділянку цілі, яка має ЗІБЗ;

$$
\begin{gathered}
S^{3 x}-\text { площа захищеної } \quad \text { ділянки цілі } \\
\left(S^{3 x}=S^{б ш}+S^{б ж}\right)\left(\mathrm{m}^{2}\right) ; \\
S_{u}-\text { загальна площа цілі }\left(\mathrm{m}^{2}\right) .
\end{gathered}
$$



ЗІБЗ, що входить у формулу (3), пропонується застосовувати захисний коефіцієнт цілі, який характеризує ступінь захисту цілі на ефективній дальності стрільби зі стрілецької зброї. Цей коефіцієнт обчислюється як співвідношення величини кінетичної енергії кулі, яку може витримати бронежилет, до кінетичної енергії кулі у точці зустрічі ії з ціллю [9] за формулою:

$$
K_{u}^{3 a x}=\frac{E_{б \varkappa}}{E_{\kappa}},
$$

де $K_{u}^{3 a x}-$ захисний коефіцієнт цілі;

$$
E_{\text {бж }} \text { - порогове значення кінетичної енергії }
$$

кулі, яку здатний витримати захисний елемент засобу ІБЗ, (Дж);

$E_{\kappa}$ - кінетична енергія кулі у точці зустрічі 3 ціллю (Дж).

Таким чином, вираз для визначення імовірності пробиття кулею ЗІБЗ, можна записати у вигляді:

$$
P_{n p \bar{\sigma}}^{3 i \sigma_{3}}=\frac{1}{K_{u}^{3 a x}}=\frac{E_{\kappa}}{E_{\text {бж}}},
$$

де $P_{n p б}^{3 і б з}$-імовірність пробиття кулею захищеної ділянки цілі, яка має ЗІБЗ;

$E_{\text {бж }}$ - порогове значення кінетичної енергії кулі, яку здатний витримати захисний елемент засобу ІБЗ, (Дж);
Для обчислення імовірності пробиття кулею

$E_{\kappa}$ - кінетична енергія кулі у точці зустрічі 3 ціллю (Дж).

Підставивши вирази (5), (6), (7) у формулу (3), зробивши ряд математичних перетворень та спрощень отримуємо вираз, для визначення імовірності пораження захищеної одиночної цілі, яка визначає зв'язок між площинами незахищених і захищених ділянок цілі з загальною площею цілі, енергетичним потенціалом засобу вогневого ураження і ЗІБЗ:

$$
P_{\Pi Ц}^{3 i \sigma_{3}}=\frac{S^{3 x} \cdot E_{\kappa}+E_{\text {бж}} \cdot S^{H 3 x}}{S_{u} \cdot E_{\text {бж }}}
$$

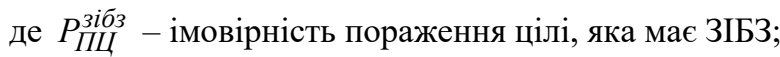

$S^{3 x}$ - площа захищеної ділянки цілі $\left(\mathrm{m}^{2}\right)$;

$S^{\text {нзx }}$ - площа незахищеної ділянки цілі $\left(\mathrm{M}^{2}\right)$;

$S_{u}$ - загальна площа цілі $\left(\mathrm{м}^{2}\right)$;

$E_{\text {бж }}$ - порогове значення кінетичної енергії кулі, яку здатний витримати захисний елемент засобу ІБЗ, (Дж);

$E_{\kappa}$ - кінетична енергія кулі у точці зустрічі 3 ціллю (Дж).

3 використанням формули (9) проведено розрахунки імовірності пораження цілі, що оснащена ЗІБЗ, для зазначеного виду стрілецької зброї, боєприпасів та ЗІБЗ, з урахуванням ефективної дальності стрільби. Результати розрахунків наведено в табл. 3.

\begin{tabular}{|c|c|c|c|c|c|c|c|c|c|c|c|c|c|}
\hline \multirow[t]{2}{*}{$\begin{array}{l}\text { № } \\
\text { 3/ח }\end{array}$} & \multirow[t]{2}{*}{$\begin{array}{l}\text { Вид } \\
\text { зброї }\end{array}$} & \multirow{2}{*}{$\begin{array}{c}\text { Тип } \\
\text { патрона }\end{array}$} & \multirow[t]{2}{*}{$\begin{array}{l}\text { Засіб } \\
\text { ІБ3 }\end{array}$} & \multicolumn{10}{|c|}{$\begin{array}{c}\text { Імовірність пораження } P_{П Ц Ц}^{3 і б з} \text { цілі, } \\
\text { яка має ЗІБЗ на ефективній дальності стрільби } D(м)\end{array}$} \\
\hline & & & & 50 & 100 & 150 & 200 & 250 & 300 & 350 & 400 & 450 & 500 \\
\hline \multirow{2}{*}{1.} & \multirow{2}{*}{ АК-74 } & \multirow{2}{*}{$\begin{array}{c}5,45 \times 39 \mathrm{MM} \\
\text { ПС }\end{array}$} & $\begin{array}{c}\text { Бр4 } \\
(6523)\end{array}$ & 0,740 & 0,660 & 0,588 & 0,526 & 0,471 & 0,421 & 0,378 & 0,340 & 0,306 & 0,276 \\
\hline & & & $\begin{array}{c}\text { Бр5 } \\
\text { (6Б43) }\end{array}$ & 0,379 & 0,337 & 0,3 & 0,267 & 0,239 & 0,213 & 0,191 & 0,171 & 0,153 & 0,138 \\
\hline \multirow{2}{*}{2.} & \multirow{2}{*}{ РПК-74 } & \multirow{2}{*}{$\begin{array}{c}5,45 \times 39 \mathrm{MM} \\
\Pi \mathrm{C}\end{array}$} & $\begin{array}{c}\text { Бр4 } \\
(6523)\end{array}$ & 0,836 & 0,744 & 0,663 & 0,591 & 0,529 & 0,473 & 0,423 & 0,380 & 0,342 & 0,307 \\
\hline & & & $\begin{array}{c}\text { Бр5 } \\
(6 Б 43)\end{array}$ & 0,428 & 0,381 & 0,339 & 0,301 & 0,269 & 0,24 & 0,214 & 0,191 & 0,171 & 0,154 \\
\hline \multirow{2}{*}{3.} & \multirow{2}{*}{$\begin{array}{l}\text { Вулкан- } \\
\text { М } \\
\text { АК-ТК } \\
\text { АКМ }\end{array}$} & \multirow{2}{*}{$\begin{array}{c}7,62 \times 39 \mathrm{MM} \\
\text { ПС }\end{array}$} & $\begin{array}{c}\text { Бр4 } \\
(6523)\end{array}$ & 0,999 & 0,926 & 0,816 & 0,720 & 0,635 & 0,562 & 0,497 & 0,442 & 0,393 & 0,350 \\
\hline & & & $\begin{array}{c}\text { Бр5 } \\
(6 Б 43)\end{array}$ & 0,541 & 0,475 & 0,418 & 0,368 & 0,324 & 0,286 & 0,253 & 0,224 & 0,198 & 0,176 \\
\hline \multirow{2}{*}{4.} & \multirow{2}{*}{ ПК } & \multirow{4}{*}{$\begin{array}{c}7,62 \times 54 \mathrm{MM} \\
\text { ЛПС }\end{array}$} & $\begin{array}{c}\text { Бр4 } \\
\text { (6Б23) }\end{array}$ & 0,999 & 0,999 & 0,999 & 0,999 & 0,999 & 0,999 & 0,912 & 0,822 & 0,742 & 0,670 \\
\hline & & & $\begin{array}{c}\text { Бр5 } \\
(6 Б 43)\end{array}$ & 0,883 & 0,794 & 0,713 & 0,641 & 0,577 & 0,519 & 0,467 & 0,421 & 0,379 & 0,342 \\
\hline \multirow{2}{*}{5.} & \multirow[t]{2}{*}{ СВД } & & $\begin{array}{c}\text { Бр4 } \\
(6 Б 23)\end{array}$ & 0,999 & 0,999 & 0,999 & 0,999 & 0,999 & 0,999 & 0,921 & 0,831 & 0,750 & 0,678 \\
\hline & & & $\begin{array}{c}\text { Бр5 } \\
(6 Б 43)\end{array}$ & 0,894 & 0,803 & 0,722 & 0,649 & 0,584 & 0,525 & 0,473 & 0,426 & 0,384 & 0,346 \\
\hline
\end{tabular}

Таблиця 3

Імовірність пораження цілі, що оснащена ЗІБЗ на ефективній дальності стрільби

\footnotetext{
Джерело: розроблено авторами.
} 
В (табл. 4) наведені результати розрахунку, очікуваної кількості патронів $N_{O Д}^{3 і б з}$, необхідної для гарантованого пораження одиночної захищеної цілі, зазначеними зразками стрілецької зброї, боєприпасами на відповідній дальності стрільби.

Розрахунок виконувався за формулою (4).

Таблиця 4

Очікувана кількість патронів необхідна для гарантованого пораження одиночної цілі, яка має ЗІБЗ на ефективній дальності стрільби

\begin{tabular}{|c|c|c|c|c|c|c|c|c|c|c|c|c|c|}
\hline \multirow[t]{2}{*}{$\begin{array}{l}\text { № } \\
\text { 3/ח }\end{array}$} & \multirow[t]{2}{*}{$\begin{array}{l}\text { Вид } \\
\text { зброї }\end{array}$} & \multirow[t]{2}{*}{$\begin{array}{c}\text { Тип } \\
\text { патрона }\end{array}$} & \multirow[t]{2}{*}{$\begin{array}{l}\text { Засіб } \\
\text { ІБ3 }\end{array}$} & \multicolumn{10}{|c|}{$\begin{array}{c}\text { Очікувана кількість патронів } N_{O Д}^{\text {зібз }} \text { для пораження одиночної цілі, } \\
\text { яка має ЗІБЗ на дальності стрільби } D \text { (м) }\end{array}$} \\
\hline & & & & 50 & 100 & 150 & 200 & 250 & 300 & 350 & 400 & 450 & 500 \\
\hline \multirow[t]{4}{*}{1.} & \multirow{4}{*}{ AK-74 } & \multirow{4}{*}{$\begin{array}{c}5,45 \times 39 \mathrm{MM} \\
\Pi \mathrm{C}\end{array}$} & \multirow{2}{*}{$\begin{array}{c}\text { Бр44 } \\
(6523) \\
\end{array}$} & 1,351 & 1,515 & 1,701 & 1,901 & 2,123 & 2,375 & 2,646 & 2,941 & 3,268 & 3,623 \\
\hline & & & & \multicolumn{5}{|c|}{2} & \multicolumn{3}{|c|}{3} & \multicolumn{2}{|c|}{4} \\
\hline & & & \multirow{2}{*}{$\begin{array}{c}\text { Бр5 } \\
(6 \text { Б43) }\end{array}$} & 2,64 & 2,968 & 3,333 & 3,74 & 4,192 & 4,693 & 5,246 & 5,857 & 6,528 & 7,263 \\
\hline & & & & \multicolumn{3}{|c|}{3} & \multicolumn{2}{|c|}{4} & \multicolumn{2}{|c|}{5} & 6 & \multicolumn{2}{|c|}{1} \\
\hline \multirow[t]{4}{*}{2.} & \multirow{4}{*}{ РПК-74 } & \multirow{4}{*}{$\begin{array}{c}5,45 \times 39 \mathrm{MM} \\
\text { ПС }\end{array}$} & \multirow{2}{*}{$\begin{array}{c}\text { Бр4 } \\
\text { (6Б23) }\end{array}$} & 1,196 & 1,344 & 1,508 & 1,692 & 1,89 & 2,114 & 2,364 & 2,632 & 2,924 & 3,257 \\
\hline & & & & \multicolumn{5}{|c|}{2} & \multicolumn{4}{|c|}{3} & 4 \\
\hline & & & \multirow{2}{*}{$\begin{array}{c}\text { Бр5 } \\
\text { (6Б43) }\end{array}$} & 2,336 & 2,628 & 2,954 & 3,318 & 3,723 & 4,173 & 4,671 & 5,223 & 5,831 & 6,499 \\
\hline & & & & \multicolumn{3}{|c|}{3} & \multicolumn{2}{|c|}{4} & \multicolumn{2}{|c|}{5} & \multicolumn{2}{|c|}{6} & 7 \\
\hline \multirow[t]{4}{*}{3.} & \multirow{4}{*}{$\begin{array}{l}\text { Вулкан- } \\
\text { М } \\
\text { АК-ТК } \\
\text { АКМ }\end{array}$} & \multirow{4}{*}{$\begin{array}{c}7,62 \times 39 \mathrm{MM} \\
\Pi \mathrm{C}\end{array}$} & & 1,001 & 1,080 & 1,225 & 1,389 & 1,575 & 1,779 & 2,012 & 2,262 & 2,545 & 2,857 \\
\hline & & & (6Б23) & & 1 & & & & & & & 3 & \\
\hline & & & Бр5 & 1,85 & 2,104 & 2,392 & 2,716 & 3,082 & 3,494 & 3,955 & 4,472 & 5,048 & 5,69 \\
\hline & & & (6Б43) & & 2 & & & & & & & & 6 \\
\hline 4. & & & Бр4 & 1,001 & 1,001 & 1,001 & 1,001 & 1,001 & 1,001 & 1,096 & 1,217 & 1,348 & 1,493 \\
\hline & חर & & (6Б23) & & & & 1 & & & & & 2 & \\
\hline & $11 K$ & & Бр5 & 1,132 & 1,26 & 1,402 & 1,559 & 1,733 & 1,926 & 2,139 & 2,375 & 2,635 & 2,922 \\
\hline & & $7,62 \times 54 \mathrm{MM}$ & $(6 Б 43)$ & & & & 2 & & & & & 3 & \\
\hline 5. & СВД & ЛПС & Бр4 & 1,001 & 1,001 & 1,001 & 1,001 & 1,001 & 1,001 & 1,086 & 1,203 & 1,333 & 1,475 \\
\hline & & & (6Б23) & & & & 1 & & & & & 2 & \\
\hline & & & Бр5 & 1,119 & 1,245 & 1,386 & 1,541 & 1,713 & 1,904 & 2,115 & 2,348 & 2,605 & 2,889 \\
\hline & & & (6Б43) & & & & 2 & & & & & 3 & \\
\hline
\end{tabular}

Джерело: розроблено авторами.

Користуючись розрахунковими значеннями імовірності пораження $P_{П Ц}^{3 і б з ~(т а б л . ~ 3) ~ т а ~ к і л ь к о с т і ~}$

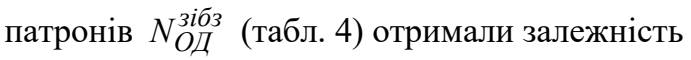

(рис. 5), що зв'язує імовірність пораження захищеної одиночної цілі з необхідною витратою боєприпасів для одиночної стрільби зі стрілецької зброї на ефективній дальності.

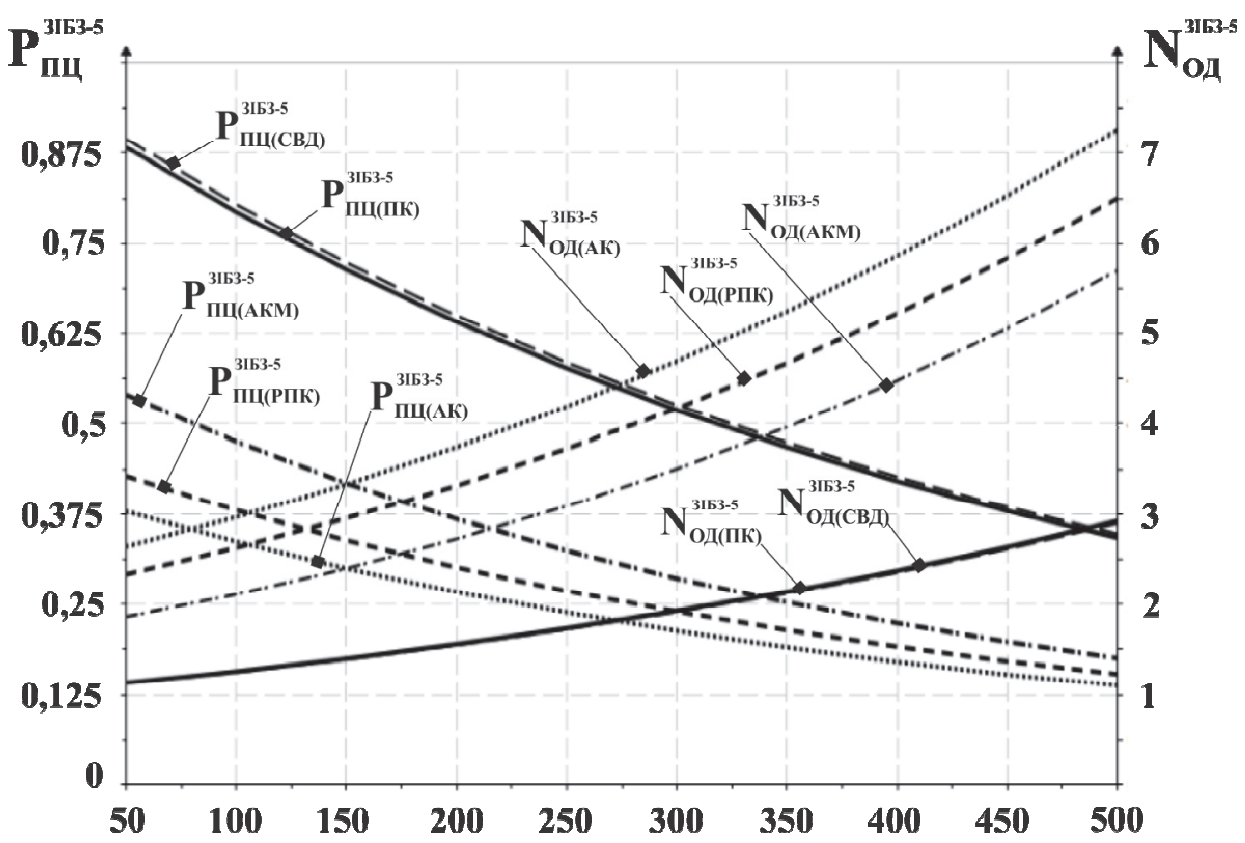

Рис. 5. Залежність імовірності пораження цілі, яка має ЗІБЗ Бр.5 та необхідна кількість патронів для її пораження одиничним вогнем на ефективній дальності стрільби Джерело: розроблено авторами. 
Аналіз отриманої залежності показує, що для пораження цілі, яка має ЗІБЗ класу захисту Бр. 5, 3 імовірністю не нижче 0,5 на дальності стрільби до 300 метрів доцільно застосовувати зброю калібру 7,62 мм., що забезпечить раціональну витрату боєкомплекту стрільця. Зброю калібру 5,45 мм., з урахуванням раціональної витрати патронів доцільно застосовувати на дальності до 100 метрів. Але це не $\epsilon$ суворим обмеженням, так для автомату АК74 дальність ефективного вогню є до 500 метрів.

Для знищення цілі, яка має ЗІБЗ класу захисту
Бр. 5, на вказаній дальності з імовірністю пораження не менше 0,5 треба зробити не менше ніж 28 пострілів.

В (табл. 5) складена порівняльна витрата необхідної кількості патронів $n$ для пораження одиночної цілі, яка не має ЗІБ3 [3], та запропонована нами, у ході дослідження очікувана кількість патронів

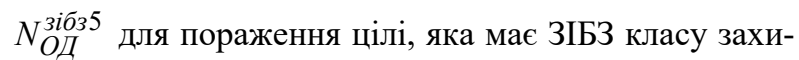
сту Бр. 5 при стрільбі одиночним вогнем для зазначених раніше умов стрільби.

Таблиця 5

Порівняльна витрата кількості патронів, що необхідна для пораження одиночної цілі, яка не має ЗІБЗ (n)

та має ЗІБЗ класу захисту Бр. $5\left(N_{O Д}^{3 і б} 5\right)$ на ефективній дальності стрільби одиночним вогнем

\begin{tabular}{|c|c|c|c|c|c|c|c|c|c|c|c|c|c|}
\hline \multirow[t]{2}{*}{$\begin{array}{l}\text { № } \\
\text { 3/ח }\end{array}$} & \multirow[t]{2}{*}{$\begin{array}{l}\text { Вид } \\
\text { зброї }\end{array}$} & \multirow[t]{2}{*}{$\begin{array}{c}\text { Тип } \\
\text { патрона }\end{array}$} & \multirow[t]{2}{*}{ Ціль } & \multicolumn{10}{|c|}{$\begin{array}{c}\text { Очікувана кількість патронів } n, N_{O Д}^{3 і б з 5} \\
\text { для пораження одиночної цілі на дальності стрільби } D(\text { м) }\end{array}$} \\
\hline & & & & 50 & 100 & 150 & 200 & 250 & 300 & 350 & 400 & 450 & 500 \\
\hline \multirow{3}{*}{1.} & \multirow{3}{*}{ АК-74 } & \multirow{3}{*}{$\begin{array}{c}5,45 \times 39 \mathrm{MM} \\
\Pi \mathrm{C}\end{array}$} & $\begin{array}{c}(n), \text { без } \\
\text { ЗІБЗ }\end{array}$ & 1 & 1 & 1 & 1 & 1 & 1 & 1 & 2 & 2 & 2 \\
\hline & & & $\left(N_{O \pi}^{3 i \sigma_{3} 5}\right)$, & 2,725 & 3,067 & 3,65 & 3,861 & 4,329 & 4,831 & 5,405 & 6,024 & 6,711 & 7,463 \\
\hline & & & у ЗІБЗ Бр5 & \multicolumn{3}{|c|}{3} & \multicolumn{2}{|c|}{4} & \multicolumn{2}{|c|}{5} & 6 & \multicolumn{2}{|c|}{7} \\
\hline \multirow{3}{*}{2.} & \multirow{3}{*}{ РПК-74 } & \multirow{3}{*}{$\begin{array}{c}5,45 \times 39 \mathrm{MM} \\
\text { ПС }\end{array}$} & $\begin{array}{c}(n), \text { без } \\
\text { ЗІБЗ }\end{array}$ & 1 & 1 & 1 & 1 & 1 & 1 & 1 & 2 & 2 & 2 \\
\hline & & & $\left(N_{O Д}^{3 i \sigma_{3} 5}\right)$ & 2,415 & 2,710 & 3,049 & 3,452 & 3,846 & 4,310 & 4,804 & 5,376 & 6,024 & 6,711 \\
\hline & & & у ЗІБЗ Бр5 & \multicolumn{3}{|c|}{3} & \multicolumn{2}{|c|}{4} & \multicolumn{2}{|c|}{5} & \multicolumn{2}{|c|}{6} & 7 \\
\hline \multirow{3}{*}{3.} & \multirow{3}{*}{$\begin{array}{l}\text { Вулкан- } \\
\text { М } \\
\text { АК-ТК } \\
\text { АКМ }\end{array}$} & \multirow{3}{*}{$\begin{array}{c}7,62 \times 39 \mathrm{MM} \\
\Pi \mathrm{C}\end{array}$} & $\begin{array}{c}(n), \text { без } \\
\text { ЗІБЗ }\end{array}$ & 1 & 1 & 1 & 1 & 1 & 1 & 1 & 2 & 2 & 2 \\
\hline & & & $\left(N_{O д}^{\text {зібз }}\right)$ & 1,912 & 2,174 & 2,469 & 2,801 & 3,185 & 3,610 & 4,082 & 4,608 & 5,208 & 5,848 \\
\hline & & & у ЗІБЗ Бр5 & \multicolumn{3}{|c|}{2} & \multicolumn{2}{|c|}{3} & \multicolumn{2}{|c|}{4} & \multicolumn{2}{|c|}{5} & 6 \\
\hline \multirow{3}{*}{4.} & \multirow{3}{*}{ ПК } & \multirow{5}{*}{$\begin{array}{c}7,62 \times 54 \mathrm{MM} \\
\text { ЛПС }\end{array}$} & $\begin{array}{c}(n), \text { без } \\
\text { ЗІБЗ }\end{array}$ & 1 & 1 & 1 & 1 & 1 & 1 & 1 & 2 & 2 & 2 \\
\hline & & & $\left(N_{O Д}^{3 i б 35}\right)$, & 1,171 & 1,302 & 1,449 & 1,61 & 1,792 & 1,988 & 2,212 & 2,451 & 2,717 & 3,021 \\
\hline & & & у ЗІБЗ Бр5 & \multicolumn{7}{|c|}{2} & \multicolumn{3}{|c|}{3} \\
\hline \multirow{2}{*}{5.} & \multirow{2}{*}{ СВД } & & $\begin{array}{c}(n), \text { без } \\
\text { ЗІБЗ }\end{array}$ & 1 & 1 & 1 & 1 & 1 & 1 & 1 & 1 & 1 & 1 \\
\hline & & & $\begin{array}{l}\left(N_{O Д}^{3 і б з 5}\right) \text {, } \\
\text { у ЗІБЗ Бр5 }\end{array}$ & 1,156 & 1,287 & 1,431 & 1,592 & 1,770 & 1,969 & 2,183 & 2,427 & 2,688 & 2,976 \\
\hline
\end{tabular}

Джерело: розроблено авторами.

Таким чином встановлено, що очікувана витрата боєприпасів при стрільбі одиночним вогнем для гарантованого пораження цілі, яка має ЗІБЗ зростає на ефективній дальності стрільби в 3,5 рази для боєприпасів калібру 5,45 мм., і в 3 рази для боєприпасів калібру 7,62 мм. При стрільбі автоматичним вогнем зі стрілецької зброї витрата боєприпасів зростає в 2,5 рази [3]. Для проведення тактичних розрахунків очікуваної витрати боєприпасів для пораження захищеного противника ЗІБЗ, зі стрілецької зброї зазначених калібрів пропонується використовувати вираз (10) для одиночного виду вогню та (11) для автоматичного вогню:

$$
N_{O д}^{3 i б з}=n \cdot k,
$$

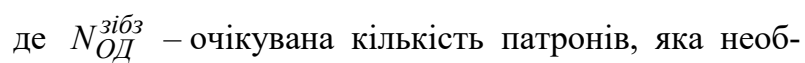
хідна для пораження одиночної цілі, що має ЗІБЗ на ефективній дальності стрільби зі стрілецької зброї одиночним вогнем;

$n$ - кількість патронів, яка необхідна для пораження одиночної цілі, що не має ЗІБЗ на ефектив- 
ній дальності стрільби зі стрілецької зброї одиночним вогнем;

$k$ - коефіцієнт, що враховує наявність у цілі ЗІБ3; $(k=3,5)$ - для стрілецької зброї калібру 5,45 мм; $(k=3)$ - для стрілецької зброї калібру 7,62 мм;

$$
N_{A B}^{3 i \sigma_{3}}=N_{O Д}^{3 i \sigma 3} \cdot K
$$

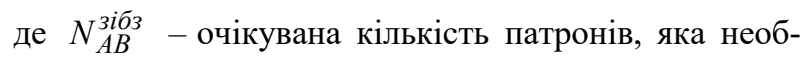
хідна для пораження одиночної цілі, що має ЗІБЗ на ефективній дальності стрільби зі стрілецької зброї автоматичним вогнем;

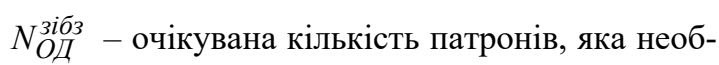

хідна для ураження одиночної цілі, що має ЗІБЗ на ефективній дальності стрільби зі стрілецької зброї одиночним вогнем;

$K$ - коефіцієнт, що враховує наявність розсіювання куль при стрільбі зі стрілецької зброї автоматичним вогнем, короткими чергами по 3 постріли на дальності стрільби 500 метрів $(K=2,5)$.

Виходячи з проведеного аналізу впливу ЗІБЗ на кількість патронів необхідну для пораження одиночної цілі, можна надати практичні рекомендації щодо обрахунку необхідної кількості патронів у боєкомплекті стрільця для виведення з ладу живої сили противника, на дальності до 500 м. (табл. 6).

Таблиця 6

Необхідна кількість патронів, для пораження захищеної одиночної цілі на дальності

\begin{tabular}{|c|c|c|c|c|}
\hline \multirow{2}{*}{$\begin{array}{l}\text { № } \\
\text { 3/ח }\end{array}$} & \multirow{2}{*}{$\begin{array}{c}\text { Вид } \\
\text { зброї }\end{array}$} & \multirow{2}{*}{$\begin{array}{c}\text { Тип } \\
\text { патрону }\end{array}$} & \multirow{2}{*}{$\begin{array}{c}\text { Вид } \\
\text { вогню }\end{array}$} & $N$ (шт) \\
\hline & & & & $D=500($ м $)$ \\
\hline 1 & 2 & 3 & 4 & 5 \\
\hline \multirow{2}{*}{1.} & \multirow{2}{*}{ AK-74 } & \multirow{4}{*}{$5,45 \times 39$ мм ПС } & ОД & 7 \\
\hline & & & $\mathrm{AB}$ & 18 \\
\hline \multirow{2}{*}{2.} & \multirow{2}{*}{ РПК-74 } & & ОД & 6 \\
\hline & & & $\mathrm{AB}$ & 15 \\
\hline \multirow[t]{2}{*}{3.} & \multirow{2}{*}{$\begin{array}{c}\text { Вулкан-М } \\
\text { АК-ТК АКМ }\end{array}$} & \multirow{2}{*}{ 7,62×39мм ПС } & ОД & 5 \\
\hline & & & $\mathrm{AB}$ & 12 \\
\hline
\end{tabular}
не більше 500 метрів
Закінчення табл. 6

\begin{tabular}{|c|c|c|c|c|}
\hline 1 & 2 & 3 & 4 & 5 \\
\hline 4. & ПК & $7,62 \times 54 \mathrm{Mм}$ & АВ & 8 \\
\cline { 1 - 1 } \cline { 5 - 5 } & СВД & ЛПС & ОД & 3 \\
\hline
\end{tabular}

Джерело: розроблено авторами.

\section{Висновки}

В ході проведеного дослідження отримали наступні результати:

1) визначено енергетичні потенціали сучасних ЗІБ3 та засобів вогневого пораження зі стрілецької зброї калібрів 5,45 та 7,62мм;

2) визначено імовірність пораження зі стрілецької зброї одиночної цілі, яка має ЗІБЗ на ефективній дальності стрільби, враховуючи ії захисний коефіцієнт, загальну площу та площі захищених і незахищених ділянок;

3) визначено кількість боєприпасів для пораження цілі, яка має ЗІБЗ на ефективній дальності стрільби зі стрілецької зброї, що перебуває на озброєнні Збройних Сил України;

4) знайдено залежність між імовірністю пораження цілі та кількістю боєприпасів, що необхідні при стрільбі на ефективній дальності;

5) визначено коефіцієнти, що враховують наявність у цілі ЗІБЗ та впливають на витрату боєприпасів для ії̈ пораження кулями калібру 5,45 і 7,62 мм;

6) запропоновано вирази для обчислення очікуваної кількості патронів, які необхідні для пораження одиночної захищеної цілі одиночним та автоматичним вогнем;

7) запропонована необхідна кількість патронів, для пораження захищеної одиночної цілі на дальності не більше 500 метрів.

Подальшим напрямком дослідження може бути аналіз впливу засобів індивідуального броньованого захисту цілі на ефективність засобів пораження: математичне очікування числа поражених цілей в умовах стрільби по атакуючому відділенню противника на ефективній дальності стрільби.

\section{Список літератури}

1. Мелькін В. Деякі аспекти становлення та розвитку засобів індивідуального броньованого захисту / В. Мелькін // Військово-історичний меридіан. - 2020. - № 1(27). - С. 155-165.

2. Наказ Генерального штабу Збройних Сил України "Про затвердження порядку використання військовослужбовцями Збройних Сил України засобів захисту та статусу зарядженості зброї відповідно до ступеня загрози № 364 від 27.09.2016". - К.: МОУ, 2016. - 6 c.

3. Таблицы стрельбы по наземным целям из стрелкового оружия калибров 5,45 и 7,62 мм. - М.: Воениздат, 1977. $-256 \mathrm{c}$.

4. Наказ Генерального штабу Збройних Сил України "Про затвердження Курсу стрільб зі стрілецької зброї і бойових машин КРП 03.032.056-2018 (01) № 160 від 17.04.2018”. - К.: ГШ ЗСУ, 2018. - 351 с.

5. Військова керівна деталізована публікація “Керівництво зі стрілецької справи. 5,45-мм автомати Калашникова (АК-74, АКС-74, АК-74Н, АКС-74Н) та 5,45-мм ручні кулемети Калашникова (РПК-74, РПКС-74, РПК-74Н,РПКС-74Н) ВКДП 7-00 (01). 01”. - К.: Варта, 2019. - 131 с.

6. Дробан О.М. Визначення узагальненого показника ефективності стрілецької зброї / О.М. Дробан, Е.Ф. Жогальський, Б.С. Федор // Військово-технічний збірник. - 2020. - № 22. - С. 61-65.

7. Шерешевский М.С. Эффективность стрельбы из стрелкового оружия / М.С. Шерешевский, А.Н. Гонтарев, Ю.В. Минаев. - М.: ЦНИИ информации, 1979. - С. 238-263. 
8. Буравлев А.И. Методика обоснования показателя эффективности базового комплекта боевой индивидуальной экипировки военнослужащего / А.И. Буравлев, А.В. Захаров // Вооружение и экономика. - 2013. - № 3(24). - С. 32-41.

9. Аналіз механізмів ураження цілі, яка має засоби індивідуального броньованого захисту зі стрілецької зброї на основі енергетичного потенціалу та сили удару кулі 5,45 мм, 5,56 мм, 7,62 мм / А.В. Лисиця, І.М. Тіхонов, В.В. Василенко, В.О. Явтушенко // Системи озброєння і військова техніка. - 2020. - № 3(63). $\quad$ - С. 69-77. https://doi.org/10.30748/soivt.2020.63.10.

10. Семиколенов Н.П. Основы стрельбы из оружия стрелковых подразделений / Н.П. Семиколенов, Ф.Г. Бондаренко, Н.Я. Краснер. - М.: ВИ МО СССР, 1958. - 266 с.

11. Основы военно-технических исследований. Теория и приложения: монография: в 10 т. Т.9. / И.Б. Чепков, С.В. Лапицкий и др. - К.: Издательский дом Дмитрия Бугаро, 2015. -504 с.

12. Зливка Г.А. Удосконалення методики виконання прийомів і правил стрільби з урахуванням впливу засобів індивідуального бронезахисту / Г.А. Зливка, В.О. Явтушенко, С.М. Телюков // Збірник наукових праць Харківського національного університету Повітряних Сил. - 2020. - № 4(66). - С. 107-112. https://doi.org/10.30748/zhups.2020.66.15.

13. Біленко О.І. Показники та критерії оцінювання ефективності стрільби при виконанні специфічних завдань силами безпеки / О.І. Біленко // Системи озброєння і військова техніка. - 2014. - № 3(39). - С. 7-11.

Надійшла до редколегії 19.04.2021

Схвалена до друку 12.05.2021

\section{Відомості про авторів:}

\section{Лисиця Андрій Вікторович}

викладач

Харківського національного університету

Повітряних Сил ім. І. Кожедуба,

Харків, Україна

https://orcid.org/0000-0002-6632-4740

\section{Гузченко Сергій Вікторович}

кандидат військових наук

начальник кафедри

Харківського національного університету

Повітряних Сил ім. І. Кожедуба,

Харків, Україна

https://orcid.org/0000-0002-3562-6172

\section{Телюков Сергій Миколайович}

кандидат технічних наук

старший викладач

Харківського національного університету

Повітряних Сил ім. І. Кожедуба,

Харків, Україна

https://orcid.org/0000-0002-0067-8028

\section{Козлов Дмитро Михайлович}

старший викладач

Харківського національного університету

Повітряних Сил ім. Івана Кожедуба,

Харків, Україна

https://orcid.org/0000-0002-5647-0218
Information about the authors:

\author{
Andrii Lysytsia \\ Instructor \\ of Ivan Kozhedub Kharkiv \\ National Air Force University, \\ Kharkiv, Ukraine \\ https://orcid.org/0000-0002-6632-4740
}

\section{Segiy Guzchenko}

Candidate of Military Sciences

Head of Department

of Ivan Kozhedub Kharkiv National

Air Force University,

Kharkiv, Ukraine

https://orcid.org/0000-0002-3562-6172

\section{Segiy Telyukov}

Candidate of Technical Sciences

Senior Instructor

of Ivan Kozhedub Kharkiv National

Air Force University,

Kharkiv, Ukraine

https://orcid.org/0000-0002-0067-8028

\section{Dmitro Kozlov}

Senior Instructor

of Ivan Kozhedub Kharkiv National

Air Force University,

Kharkiv, Ukraine

https://orcid.org/0000-0002-5647-0218

\section{АНАЛИЗ ВЛИЯНИЯ ЗАЩИТНЫХ СВОЙСТВ СРЕДСТВ ИНДИВИДУАЛЬНОЙ БРОНИРОВАННОЙ ЗАЩИТЫ НА НЕОБХОДИМОЕ КОЛИЧЕСТВО БОЕПРИПАСОВ ДЛЯ ПОРАЖЕНИЯ ЖИВОЙ СИЛЫ ПРОТИВНИКА ИЗ СТРЕЛКОВОГО ОРУЖИЯ}

\section{А.В. Лисица, С.В. Гузченко, С.Н. Телюков, Д.М. Козлов}

В статье проведен анализ влияния защчитных свойств средств индивидуальной бронированной защиты на расход боеприпасов для поражения защищенной цели. Исследуется изменение ожидаемого количества патронов, необходимого для поражения защищенной цели в зависимости от вида оружия, типа патрона на расстоянии эффективной стрельбы из стрелкового оружия. Дан обзор зависимости вероятности поражения защищенной цели и ожидаемого количества патронов, сделан вывод, о влиянии класса защитной структуры бронежилета на расход патронов различных калибров. Рассмотрены актуальность поражения защищенных иелей противника средствами индивидуальной бронированной защиты, изготовленных из высококачественных полимерных материалов: “Арус" и “Русар". Результаты работы могут быть использованы при формировании требований к правилам стрельбы по защищенным целям, а также при уточнении предварительных расчетов таблиц стрельбы из стрелкового оружия.

Ключевые слова: средство индивидуальной бронированной защиты, эффективная дальность стрельбы, вероятность поражения цели, ожидаемое количество патронов, защитный коэффициент цели. 


\title{
ANALYSIS OF THE INFLUENCE OF THE PROTECTIVE PROPERTIES OF INDIVIDUAL ARMORED PROTECTION EQUIPMENT ON THE NECESSARY AMOUNT OF AMMUNITION FOR INJURY
}

\author{
A. Lisitsya, S. Guzchenko, S.Telyukov, D. Kozlov
}

The article analyzes the impact of the protective properties of personal armor on the consumption of ammunition to hit the protected target. The change in the expected number of rounds required to hit a protected target depending on the type of weapon, the type of cartridge at a distance of effective firing from small arms is investigated. An overview of the dependence of the probability of damage to the protected target and the expected number of rounds is given, a conclusion is made regarding the influence of the class of the protective structure of the bulletproof vest on the consumption of cartridges of different calibers. The urgency of defeating the enemy's protected targets by means of individually armored protection made of high-quality polymeric materials: "Arus" and "Rusar" is considered. The formula for determining the probability of hitting a protected target based on knowledge of its total area, the planes of the unprotected and protected area and the protection factor is proposed for use. The energy potentials of modern bulletproof vests and firearms from small arms of caliber 5.45 and $7.62 \mathrm{~mm}$ have been determined. The required number of rounds to hit a protected single target at a range of 500 meters. It is established that the consumption of ammunition to hit a single protected target increases 3.5 times in relation to the target, which has no means of individual armored protection. The method of evaluating the effectiveness of shooting by the criteria: the probability of hitting the target and the expected consumption of ammunition when firing single and automatic fire. The results of the work can be used in the formation of requirements for the rules of shooting at protected targets, as well as in clarifying the preliminary calculations of the tables of shooting from small arms.

Keywords: means of individual armor protection, effective firing range, the probability of hitting the target, the expected number of rounds, the protective factor of the target. 